\title{
Let's Get Physical: Bacterial-Fungal Interactions and Their Consequences in Agriculture and Health
}

\author{
Breanne N. Steffan ${ }^{1}\left(\mathbb{D}\right.$, Nandhitha Venkatesh ${ }^{1,2}$ and Nancy P. Keller $1,3, * \mathbb{C}$ \\ 1 Department of Medical Microbiology and Immunology, University of Wisconsin-Madison, Madison, \\ WI 53706, USA; bsteffan@wisc.edu (B.N.S.); thiruvannama@wisc.edu (N.V.) \\ 2 Department of Plant Pathology, University of Wisconsin-Madison, Madison, WI 53706, USA \\ 3 Department of Bacteriology, University of Wisconsin-Madison, Madison, WI 53706, USA \\ * Correspondence: npkeller@wisc.edu
}

Received: 31 August 2020; Accepted: 20 October 2020; Published: 23 October 2020

\begin{abstract}
Fungi serve as a biological scaffold for bacterial attachment. In some specialized interactions, the bacteria will invade the fungal host, which in turn provides protection and nutrients for the bacteria. Mechanisms of the physical interactions between fungi and bacteria have been studied in both clinical and agricultural settings, as discussed in this review. Fungi and bacteria that are a part of these dynamic interactions can have altered growth and development as well as changes in microbial fitness as it pertains to antibiotic resistance, nutrient acquisition, and microbial dispersal. Consequences of these interactions are not just limited to the respective microorganisms, but also have major impacts in the health of humans and plants alike. Examining the mechanisms behind the physical interactions of fungi and bacteria will provide us with an understanding of multi-kingdom community processes and allow for the development of therapeutic approaches for disease in both ecological settings.
\end{abstract}

Keywords: bacterial-fungal interactions; adhesion; attachment; endofungal

\section{Introduction}

Fungi and bacteria coexist creating complex communities that are important in agriculture and human health. Although originally mostly studied in agricultural environments (e.g., arbuscular mycorrhizal-bacterial [1] and Rhizopus-Mycetohabitans (formerly Burkholderia [2]) symbioses [3]), bacterial-fungal interactions (BFI) are now recognized as the norm in most ecological settings. In fact, identifying microorganisms that make up these communities has been the focus of numerous studies such as the Human Microbiome Project started by the National Institutes of Health (NIH) in 2007 [4].

BFIs are commonly studied in biofilms, where both microbes physically interact, often exchanging or responding to each other's metabolites. Studying their direct physical interactions informs researchers of their collective behavior on survival, production of secondary metabolites (that find use as clinical drugs, fungicides, prebiotics etc.), dissemination of the organisms to different environments, and identification of mechanisms that facilitate these types of interactions. As we will show in this review, direct physical interactions of bacteria and fungi typically present with fungi as scaffolds where bacteria can be external or internal to the fungus. These physical interactions can be dependent on the microbial partner, the host (if any) of the BFI, and even the substrate for growth. We will address the findings across practices-in agriculture and clinical settings-to call attention to a unified outlook on the ecology of how microbes interact. We propose that the combined insight with respect to microbial ecology can aid in obtaining a better understanding of clinical and agricultural outcomes 
and help to identify novel methods for disease control and the promotion of good health of plants as well as humans.

\section{Bacterial-Fungal Physical Interactions}

Bacteria can be associated with fungi (externally and internally) and the type of interaction depends not only on the morphology of the fungal organisms but also on fungal and bacterial surface molecules and secreted factors. Most but not all fungi form extensive filaments called hyphae that are penetrative into the surrounding environment, be it the rhizosphere, organic matter, or a living host. While many BFIs are characterized by bacteria interacting with hyphal and fungal spore surfaces, there is growing evidence of bacterial invasion into fungal structures. Mechanisms of bacterial attachment to fungal surfaces and their invasion of fungal organisms are highlighted in this section (Table 1).

Table 1. Mediators of Bacterial-Fungal Interactions (BFIs).

\begin{tabular}{|c|c|c|}
\hline Mediators & BFI & Citation \\
\hline \multicolumn{3}{|l|}{ Surface molecules } \\
\hline $\begin{array}{l}\text { Als Proteins and } \\
\text { O-mannosylations }\end{array}$ & S. epidermidis-C. albicans & Beaussart, 2013 \\
\hline Als3p & $\begin{array}{l}\text { S. gordonii-C. albicans } \\
\text { S. aureus-C. albicans }\end{array}$ & $\begin{array}{l}\text { Silverman, } 2010 \\
\text { Peters, } 2012\end{array}$ \\
\hline Als adhesins, SasF, Atl & S. aureus-C. albicans & Schlecht, 2015 \\
\hline $\mathrm{CbpD}$ & P. aeruginosa-C. albicans & Ovchinnikova, 2013 \\
\hline T2SS & M. rhizoxinica-R. microsporus & Moebius, 2014 \\
\hline T3SS & M. rhizoxinica-R. microsporus & Lackner, 2011 \\
\hline $\begin{array}{l}\text { T2SS, T3SS, T4SS, gspD, } \\
\text { sec system }\end{array}$ & M. rhizoxinica-R. microsporus & Ghignone, 2012 \\
\hline TAL effector & M. rhizoxinica-R. microsporus & Richter, 2020; Carter, 2020 \\
\hline \multicolumn{3}{|l|}{ Genes } \\
\hline$g s p D, \sec B$ & Ca. G. gigasporum-G. margarita & Ghignone, 2011 \\
\hline vacB & Burkholderia sp.-G. margarita & Ruiz-Lozano \& Bonfante, 2000 \\
\hline spo0A & $\begin{array}{l}\text { B. subtilis- } A \text {. niger } \\
\text { B. subtilis- } A g \text {. bisporus }\end{array}$ & Kjeldgaard, 2019 \\
\hline \multicolumn{3}{|l|}{ Secreted Factors } \\
\hline EPS and TasA & $\begin{array}{l}\text { B. subtilis- } A \text {. niger } \\
\text { B. subtilis- } A \text {. bisporus }\end{array}$ & Kjeldgaard, 2019 \\
\hline $\begin{array}{l}\text { GAG, pyo-melanin, } \\
\text { 1,8-dihydroxynaphthalene- } \\
\text { melanin }\end{array}$ & P. aeruginosa- $A$. fumigatus & Briard, 2017 \\
\hline $\mathrm{ECM}$ & S. aureus- C. albicans & Harriot and Noverr, 2009 \\
\hline Holrhizin A & M. rhizoxinica-R. microsporus & Moebius, 2014 \\
\hline Ralsolamycin & R. solanacearum-A. flavus & Spraker, 2016 \\
\hline $\begin{array}{l}\text { Progidiosin, T6SS, TssJ, } \\
\text { murein lipoprotein }\end{array}$ & S. marcescens-M. irregularis & Hazarika, 2020 \\
\hline \multicolumn{3}{|l|}{ Other } \\
\hline Acid-Base Attractive Forces & P. aeruginosa-C. albicans & Ovchinnikova, 2012 \\
\hline Fungal Viability & $\begin{array}{l}\text { B. cereus-Glomus sp. } \\
\text { P. peoriae-Glomus sp. } \\
\text { P. brasilensis-Glomus sp. } \\
\text { S. marcescens-A. fumigatus } \\
\text { S. marcescents-R. oryzae }\end{array}$ & $\begin{array}{l}\text { Toljander, } 2006 \\
\text { Hover, } 2016\end{array}$ \\
\hline
\end{tabular}

\subsection{Bacterial Attachment to the External Surface of Fungi}

Both clinical and agricultural settings have made great strides in addressing the mechanisms associated with bacterial attachment to fungal surfaces. Surface molecules and secreted factors drive the interactions between bacteria and fungi, though the response seems to be specific to the 
respective microorganisms. In this subsection, we will discuss factors contributing to the formation of BFIs across clinical and agricultural disciplines.

\subsubsection{Human Pathogenic Fungi and Their Bacterial Interactions}

Candida albicans is a human commensal that can, in immunocompromised patients or in situations of microbiome dysbiosis, cause candidiasis. It is a pleomorphic fungus with yeast and hypha being its most common morphologies. BFIs are commonly formed between Candida spp. and several types of bacteria. Staphylococcus, Streptococcus, and Pseudomonas are three genera commonly associated with C. albicans where they adhere preferentially to the hypha and not the yeast cell [5-9]. Adherence of the bacteria to the hypha is dependent on fungal and bacterial surface molecules and secreted factors.

Adhesins are a class of surface molecules that facilitate bacterial attachment to the fungal hypha. Deletion of adhesin molecules are associated with reduced bacterial attachment to C. albicans by bacteria including Staphylococcus epidermidis [8], Staphylococcus aureus [10,11], and Streptococcus gordonii [9]. Beaussart et al. identified both agglutinin-like sequence (Als) proteins and O-mannosylations as important factors involved in S. epidermidis attaching to C. albicans [8]. The C. albicans adhesin agglutinin-like sequence 3 (Als3p) is implicated in the adherence of the bacteria, S. aureus and S. gordonii, to the fungus [9-11]. Als3p is a hyphal-specific glycoprotein that facilitates biofilm formation and binding to the host cells and extracellular matrix $[9,12]$. Initial work studying this adhesin in mediating BFIs found that $S$. gordonii attaches to C. albicans Als3p via the bacterial expression of the surface protein adhesin, SspB [9]. In similar studies, the fungal Als3p has also been found to be involved in the attachment of $S$. aureus to $C$. albicans $[10,11]$.

Use of a C. albicans als3 mutant demonstrated the reduced ability of $S$. aureus to bind to the fungal hypha via several tests including measuring adhesion forces, microscopy, and immunoassays [10]. As Als3p is also implicated in the attachment and invasion of $C$. albicans hyphae on mammalian tissue, mouse tongues were used ex vivo to show that, while the $\Delta a l s 3$ strain hyphae were able to penetrate into the subepithelial layer, S. aureus was not able to adhere to the hyphae, and thus they could not be found in the subepithelium. This is in contrast with the wild-type (WT) C. albicans-S. aureus interaction in which the bacterium was found attached to invading hyphae located in the subepithelium [10]. This group later used a murine in vivo study to reiterate the importance of Als3p in facilitating the attachment of $S$. aureus to $C$. albicans. They showed that in WT C. albicans-S. aureus interactions, the bacteria bind to the hyphae and uses its BFI to invade and disseminate throughout host tissue resulting in greater morbidity and mortality of the mice. In contrast, the deletion of Als3p in C. albicans reduces $S$. aureus binding and dissemination in the host thus resulting in better survival outcomes for the animals [11]. Like the C. albicans-S. gordonii BFI, S. aureus attachment to C. albicans is also mediated by bacterial adhesins $[9,11]$. There were several staphylococcal mutants that showed a reduction in attachment to $C$. albicans including those lacking the fibronectin binding protein B, the surface protein SasF, and the bifunctional autolysin Atl. In this study, the adhesion of S. aureus to C. albicans was not completely abrogated, which suggests that there may be other factors that contribute to the attachment of the bacteria to hyphae in this BFI [11].

C. albicans has also been found to interact with the Gram-negative bacterium, P. aeruginosa in clinical disorders like cystic fibrosis. There are a few different mechanisms that have been found to contribute to P. aeruginosa binding to $C$. albicans. One such factor is in the hydrophobicity of the hyphae. As P. aeruginosa preferentially binds to the hyphae, one research group questioned the impact of acid-base attractive forces. They found that by reducing the hydrophobicity of the hyphae via a pronase treatment, there is a reduction in the binding of P. aeruginosa to C. albicans. This could be due in part to the loss of the mannoprotein layer [6]. The chitin-binding protein, $\mathrm{CbpD}$ found expressed by $P$. aeruginosa also impacts the C. albicans-P. aeruginosa BFI as Cbpd P. aeruginosa mutants show reduced adherence to the hyphae of $C$. albicans. This attachment can be restored by complementing with $\mathrm{CbpD}[5]$. 
P. aeruginosa also binds to the filamentous pathogen Aspergillus fumigatus. Together, these organisms have been found to cause poor health outcomes in cystic fibrosis patients [13]. In a study by Briard et al. P. aeruginosa secreted dirhamnolipids that induced the production of an A. fumigatus extracellular matrix (ECM) enriched in galactosaminogalactan (GAG), 1,8-dihydroxynaphthalene-melanin, and pyo-melanin [14]. This ECM surrounds the hyphae which facilitates P. aeruginosa binding to the site of greatest metabolic activity on the hyphae. Biochemical investigations indicated that bacteria only bound to GAG via ionic interactions. P. aeruginosa also impacts the cell wall structure of $A$. fumigatus as the fungus has a thicker cell wall in its presence. Specifically, the dirhamnolipid, diRha- $\mathrm{C}_{10}-\mathrm{C}_{10}$, produced by $P$. aeruginosa is responsible for the increased thickness of the cell wall and is correlated to increased GAG [14]. Inducing the production of ECM material can also occur in the interactions of $C$. albicans and S. aureus. The matrix produced allows the bacterium to be tightly associated with the hyphae and survive in unfavorable environments like that of serum or exposure to vancomycin [15].

\subsubsection{Hyphal Attachment in Environmental BFIs}

As with clinical BFIs, microbial partners that are in environmental BFIs have been studied to identify factors that enable their attachment, this includes fungal viability, secreted components, and surface markers. Hyphal viability influences bacterial attachment though bacteria differ in their need for live hyphae. When considering the BFI between Glomus sp. and bacteria, Bacillus cereus and Paenibacillus peoriae attach best to nonviable hypha, Pseudomonas fluorescens can bind to both living and non-living, and Paenibacillus brasilensis requires live hypha for attachment [16]. As we will later discuss in Section 3.2, some bacteria will bind to the hypha to exchange nutrients with fungi in otherwise adverse environments. Therefore, we can infer that bacteria, like P. brasilensis, interact with only live hypha to gain some competitive advantage from this BFI.

Additional studies have further characterized the movement of bacteria along the surface of hypha (termed the fungal highway-discussed in Section 3.3). In this context, dead fungal hypha may be advantageous to bacterial attachment and migration as otherwise living fungi may produce toxins that inhibit the attachment, a phenomenon that has been studied with BFIs of Serratia marcescens and A. fumigatus or Rhizopus oryzae. A mediator of these BFIs is the type I fimbriae which are involved in the attachment of $S$. marcescens to either A. fumigatus or R. oryzae. If $S$. marcescens has deficient fimbrial expression, it more effectively migrates across the fungal mycelia as there is a looser attachment formed between bacterium and fungus [17].

Bacterial secreted products are also important components in forming physical interactions with fungal partners. The soil dwelling bacterium, Bacillus subtilis, has been found to establish biofilms on the surfaces of Aspergillus niger and Agaricus bisporus mycelia. Formation of the biofilm depends on the production of bacterial secreted matrix components (exopolysaccharide (EPS) and the major biofilm matrix component (TasA) amyloid fiber) which are globally regulated by the stage 0 sporulation protein A (Spo0A). If any of these components are deleted from the genome of B. subtilis, the bacterium is no longer able to attach and form biofilms on the fungal surfaces. However, supplementing the matrix components back in facilitates the biofilm formation [18].

Surface attachment of bacteria to fungi is only one aspect of BFIs and it is likely important in establishing more complex interactions, including bacterial invasion into fungi, which will be discussed in Section 2.2.

\subsection{Bacterial Invasion into Fungi}

The very first observation of the endo-fungal lifestyle was reported as the presence of Bacteria-Like Organisms in Endogone spores [19]. It became evident from subsequent research that endo-fungal bacteria are widely present in several fungal phyla. Bacteria can be internalized into the fungal thallus-in hyphae as well as in spores. While co-evolved symbiotic bacteria and fungi have both evolved specific machinery to facilitate bacterial invasion and establishment of symbiosis, several instances of facultative 
endofungal associations have also been reported, whose mechanisms remain unknown. In this section, we will discuss mechanisms governing the establishment of endofungal lifestyle in both cases.

\subsubsection{Specialized Endofungal Symbioses}

Tightly evolved endo-fungal symbioses have so far been reported between Betaproteobacteria and the fungal phyla Mucoromycota, which is suggested to include three sub-phyla: Mucoromycotina (example: Rhizopus spp.), Glomeromycotina (example: Gigaspora spp.), and Mortierellomycotina (example: Mortierella spp.) [20]. Commonalities and differences in genotypes and phenotypes of the subphyla and the evolution of bacterial-hosting abilities of these fungi have been discussed elsewhere [21]. Each of the examples pointed to above will be discussed in the following paragraphs in this section.

BFIs in Mucoromycotina

Rhizopus microsporus, the fungus causing rice seedling blight, serves as host to two different endobacteria, Mycetohabitans rhizoxinica and M. endofungorum [22]. A co-evolved mutualism identified between $M$. rhizoxinica and R. microsporus has been well studied over the years. Rhizoxin is a mycotoxin with antimitotic properties, required for the pathogenicity of the fungus on rice seedlings. In 2005, it was discovered that the toxin is produced by the endosymbiont $M$. rhizoxinica [3]. Further examination of the BFI showed that the endobacterium controls host sporulation and colonizes both fungal hyphae and conidia, thus getting transmitted vertically [23]. Compared to other members of the genus, the genome of $M$. rhizoxinixa showed a huge reduction in size, with fewer transcriptional regulators, quorum-sensing systems, and a higher number of transposons, virulence-related genes, and putative effectors. Genomic data suggested possible nutrient exchange-the bacterium consumed host metabolites while providing certain amino acids to the fungal host [24]. Since sporulation was conditional upon successful establishment of endofungal symbiosis, this bacterial-fungal pair became a handy system to identify contributing mechanisms. Holrhizin A, a linear lipopeptide has been identified to support endofungal colonization by the bacterium. Holrhizin A exhibited biosurfactant activity, altered biofilm formation and cell motility to promote colonization [25]. Work pioneered by several research groups has discovered the involvement of effectors-Type III secretion system (T3SS) [26], transcription activator-like (TAL) effector [27,28], and Type II secretion system (T2SS) [23]. Receptors that interact with these effectors and the downstream signaling pathways eliciting specific responses remain to be identified.

\section{BFIs in Glomeromycotina}

Arbuscular mycorrhizal (AM) fungi known to mobilize nutrients from soil, form highly branched structures called arbuscules that aid in transfer of nutrients from the fungus to the plant. These fungi can also harbor bacteria, externally or internally, in both hyphae and spores. "Candidatus Glomeribacter gigasporum" (CaGg) is often found in the hyphae and spores of Gigaspora species of AM fungi. In contrast, Mollicutes-related endobacteria (Mre) are more widely associated across AMF lineages. Both $\mathrm{CaGg}$ and Mre were found in the Gigaspora margarita spores, suggesting that more than one bacterium can co-exist endofungally [29]. The AMF-endobacteria obligate symbioses have been estimated to date back to at least when these AM fungi formed ancestral symbioses with land plants [30].

The intracellular symbiosis between G. margarita and the obligate endosymbiotic bacterium $\mathrm{CaGg}$ has been studied over the years. A remarkable number of 250,000 bacteria were estimated to be present in the same fungal cell. Electron microscopy enabled identification of the endo-bacterium in the cytoplasm [1]. The obligate nature of the AM fungus presented a challenge for in vitro studies. However, using a carrot-root system with single spore inoculations and confocal microscopy, it was identified that the endosymbiotic bacteria in G. margarita were vertically transmitted via asexual spores [31]. Genomic analyses of the bacterium showed a remarkably reduced genome with 
typical determinants of symbiosis. Transcriptional s analyses also showed that the bacterium expresses Type II, III, and IV secretion systems as well as the general secretion protein D (gspD) and the sec system at different stages of the fungal life cycle [32]. The vacB gene, typically implicated in host-cell colonization by enteroinvasive bacteria, has been implicated in the establishment of the symbiosis between Burkholderia sp. and G. margarita, suggesting conserved mechanisms of bacterial invasion across eukaryotic hosts [33].

\section{BFIs in Mortierellomycotina}

Mortierella elongata, a non-pathogenic soil fungus harbors Mycoavidus cysteinexigens as its obligate endo-bacterial resident [34]. Proteomics and metabolic analyses highlighted the dependence of the endo-bacterium on its fungal host for carbon and nitrogen. Under nitrogen-deplete conditions, the fungus exhibited reduced growth but had a larger endo-bacterial population [35]. Genomic analyses showed that $M$. cysteinexigens lacked the machinery typically thought to be required for host invasion by bacteria-such as chitin degradation systems and T2SS components [36].

\subsubsection{Facultative Endofungal Associations}

In addition to obligate symbioses, BFIs with facultative endofungal behavior are also widespread. Most of such facultative associations involve Ascomycete and Basidiomycete fungi that interact with Alphaproteobacteria and Gammaproteobacteria. Like obligate symbioses, the study of facultative symbioses also began with assessment of specific interactions, but subsequent research efforts quickly showed that diverse bacteria exhibit endofungal behavior.

Rhizobium radiobacter, an endosymbiont of the fungus Piriformspora indica, contributes to the successful establishment of the symbiosis of the fungus with diverse plants [37]. From foliar endophytic fungi in Cupressaceous (Cypress family) trees, eleven endohyphal bacteria were isolated, whose genomic analyses showed absence of reduction as usually observed in obligate symbionts [38]. Although each bacterium encoded putative factors that can contribute to establishment of symbiosis, no commonalities in invasion machinery was observed. Phylogenetic analyses of diverse endohyphal bacteria from diverse foliar endophytes showed taxonomic incongruence between bacteria and their fungal hosts, suggesting a less specialized and more generalized association between the microbes [39].

In addition to endohyphal invasion, facultative associations are also observed in fungal resting spores and fruiting bodies. Ralsolamycin, a lipopeptide produced by the plant pathogen Ralstonia solanacearum facilitated the invasion of the producing bacterium into fungal chlamydospores [40]. The lipopeptide is hypothesized to increase the cell permeability, thus promoting invasion, much like Progidiosin, a red pigment produced by Serratia marcescens that increases cell membrane permeability of Mucor irregularis, which is proposed to facilitate invasion by the bacteria. In the latter case, the Type VI secretion system (T6SS) assembly protein TssJ and an outer membrane associated murein lipoprotein also showed significant up-regulation during the interaction process [41]. Chlamydospores of Serendipita indica, a biocontrol agent to fight plant disease, have traditionally harbored Rhizobia species, although recent reports have uncovered colonization by Trinickia spp. of bacteria [42]. Bacterial communities have been identified in ectomycorrhizal fungi and in saprotrophic mushrooms, where the community structure was dependent on the fungal phylogenetic groups. This variation has been attributed to variations in fruiting body chemistry, specifically to the C:N ratio and $\mathrm{pH}$ [43].

While some of these studies shed light on select mechanisms that enable specific facultative associations, the majority of the puzzle remains a mystery. Much of the molecular machinery that orchestrate endosymbiosis in specific bacterial-fungal pairs are yet to be identified. Mechanisms involved in enabling endofungal associations across diverse microbes also remain to be elucidated. 


\section{Implications of BFIs on Microbial Fitness}

As can be observed from our discussion in the previous section, fungal cells can no longer be considered as a single organism, but rather as a holobiont, as has also been proposed elsewhere [44]. Fungal cells may externally and internally contain not only bacteria, but also phages and other mycoviruses which makes these eukaryotic cells a highly dynamic microcosm. In the following sections, we discuss the ecological consequences of these BFIs on the partner microbes as it pertains to microbial fitness, nutrient acquisition, and microbial dispersal along the hyphal highway (Figure 1).

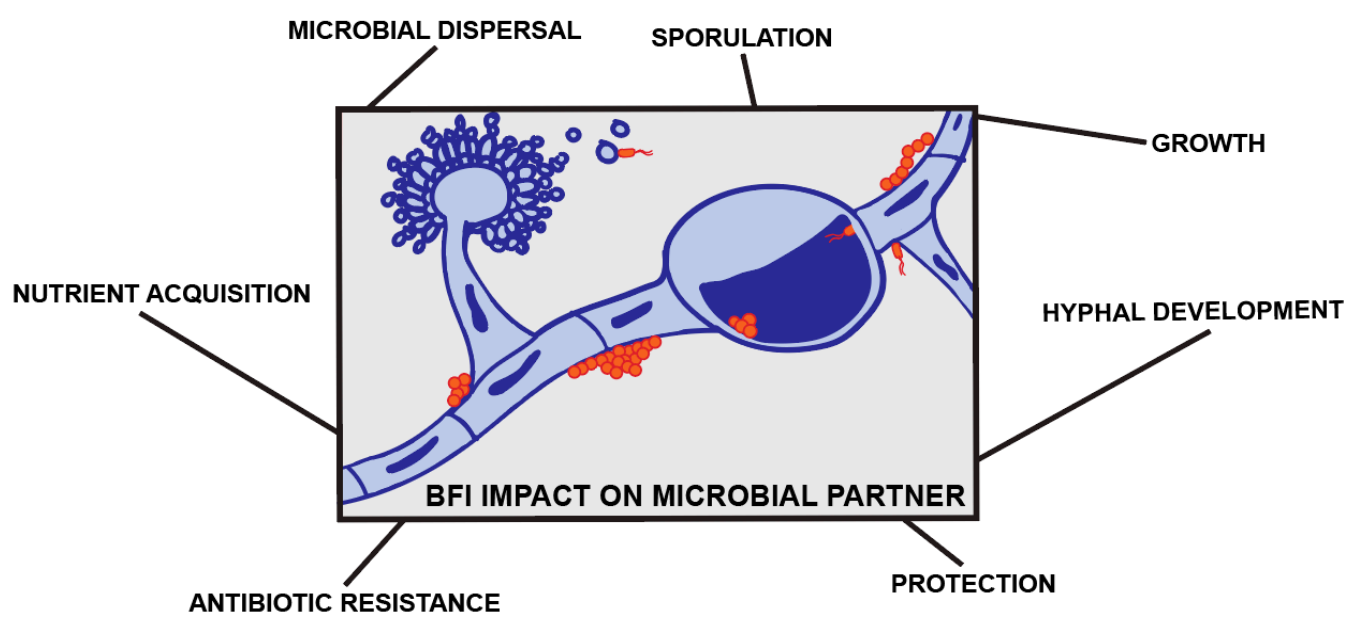

Figure 1. Bacterial-fungal interactions (BFI) impact on microbial partners. Bacterial (orange) and fungal (blue) interactions have impacts on each other's growth and development in addition to competitive advantages associated with protection, dispersal, and nutrient acquisition.

\subsection{Microbial Fitness Associated with Growth and Development of Microbial Partners}

Bacterial and fungal growth and development can be fundamental to discovering new mechanisms of physical interactions as well as provide insight into the development of agonistic and antagonistic products resulting from such interactions. Some BFIs result in developmental changes that can affect the dispersal of the organisms, while others impair biofilm formation.

The clinical A. fumigatus-P. aeruginosa BFI demonstrates the negative impact that the BFI can have on fungal growth and biofilm development. Current studies have emphasized that P. aeruginosa impairs growth and biofilm formation by $A$. fumigatus $[14,45,46]$. Early research found that the LasIR quorum-sensing network that is involved in the production of a homoserine lactone of P. aeruginosa is vital to the inhibition of the fungus. A. fumigatus growth in the presence of WT PAO1 was greatly reduced in comparison to its growth with two PAO1 quorum sensing knockout strains (PAO1: $\triangle L a s R$ and PAO1: $\Delta$ LasI). This study further found that this phenomenon also occurred with biofilm formation via indirect interactions of the bacterium and fungus [46]. The findings of this study and several others suggest that the interaction between A. fumigatus and P. aeruginosa is not just limited to the physical attachment but also in the production of compounds via indirect means that can not only affect fungal growth but also modulate the structure of the fungus [14,45-47]. As mentioned previously, the production of dirhamnolipids by P. aeruginosa promotes thicker cell walls in A. fumigatus. These lipids also cause stunted hyphal growth with hyperbranching and promote melanin production, which has been associated with reduced sensitivity to certain antifungals [14]. While there is an emphasis on the inhibition of A. fumigatus by P. aeruginosa, in the study by Briard et al., it was found that some bacterial volatile compounds could actually stimulate fungal growth [47]. Recently, a study reported that the secretome of $A$. fumigatus stimulates bacterial growth by altering the P. aeruginosa proteome [48].

The $C$. albicans-P. aeruginosa BFI is likewise impacted by products of the LasIR quorum-sensing network. It was identified that when C. albicans and P. aeruginosa are grown together, P. aeruginosa releases a diffusible factor, likely a homoserine lactone (3OC12HSL), that causes C. albicans to switch 
from hyphal growth to its yeast morphology. Other 12-carbon molecules are also able to inhibit C. albicans filamentation [49].

Establishment of successful bacterial-fungal associations, in many cases, contribute to fungal growth and/or sporulation. In the interaction between Rhizopus microsporus and Mycetohabitans rhizoxinica, fungal sporulation is contingent upon the successful establishment of symbiosis, which ensures maintenance of mutualism over generations [50]. Establishment of endofungal symbiosis between CaGg and G. margarita results in increased fungal sporulation [27]. In both cases, endobacteria are found in the spores, suggesting that control of host sporulation by endobacteria is sufficient to regulate their own transmission. The attachment of Burkholderia glumae to F. graminearum results in increased sporulation in vitro, which suggests that the BFI may result in enhanced dispersal of the fungus in the field [43]. Bacterial interactions with Penicillium roqueforti resulted in faster rate of growth and sporulation in vitro [51]. Bacteria associated with bark beetles influence growth and reproduction of their symbiotic fungi [52]. In in vitro co-cultures with the ectomycorrhizal fungus Laccaria bicolor, the mycorrhizal helper bacterium Pseudomonas fluorescens stimulates fungal radial growth, hyphal density and promotes soil colonization by the fungus [53]. Physical associations of Methylobacterium sp. P1-11 and Trinickia sp. T12-10 with Serendipita indica have been described in previous sections. In vitro co-cultures show increase in mycelial growth and sporulation and nutrient exchange [24]. Rhizobium radiobacter, the endofungal resident of $S$. indica is required for normal healthy in vitro growth and sporulation [19]. Bacterial interactions also promote growth and reproduction of numerous species of mushrooms, as reviewed elsewhere [54].

The bacterial populations that interact with fungal species can have profound impacts on fungal development. In the study by Long et al., cultivable bacteria associated with the spores of Gigaspora margarita were isolated. The majority of isolates were affiliated with Proteobacteria, Actinobacteria, and Firmicutes. Of the bacteria identified, $30.2 \%$ promoted and $11.6 \%$ inhibited spore germination. Six chitin-decomposing bacteria were also isolated from G. margarita, a potential mechanism for inducing spore germination [55]. Paenibacillus validus isolates in co-culture with Glomus intraradices stimulate hyphal growth and promote formation and maturation of spores [56].

Bacteria associated to AMF (Funneliformis caledonium, Racocetra alborosea and Funneliformis mosseae) spore wall were isolated from coastal reclamation land [28]. Bacteria belonging to phyla spanning Firmicutes, Proteobacteria, Actinobacteria, and Bacteroidetes were isolated. To characterize association characteristics, bacteria were screened for production of chitinases, proteases, cellulase enzymes and exopolysaccharide. At least one of these characteristics were found in 113 out of 120 associated bacteria.

In many agriculturally relevant BFIs, the fungal partners differentially produce mycotoxigenic compounds when interacting with their respective bacterial partners. This is particularly true for the Fusarium species of fungi, as has been reviewed earlier [57]. These mycotoxins have important ecological roles in securing the niche for the producing microbes by contributing to competitive fitness and promoting virulence characteristics for successful infection and subsequent dispersal. Recent research has found that these observations also hold true for the clinical pathogens, A. fumigatus and P. aeruginosa [58]. It is important to know that mycotoxins cause significant harm to human health upon ingestion. Research efforts to control mycotoxin production to ensure food safety can benefit from understanding BFIs in greater detail.

\subsection{Factors Obtained Via BFIs}

The obligate endofungal symbiosis between CaGg and G. maragarita enhances the fungal bioenergetic potential and ATP production and detoxification of reactive oxygen species [59]. Genomic data brought to light the extreme nutritional dependence of the bacterium for carbon, nitrogen and phosphorus on the fungus. The bacterium synthesizes vitamin B12, antibiotics, and toxin-resistant molecules which may collectively enhance the fungal ecological fitness [32]. Sweeping changes in the fungal metabolome have been reported in response to presence of the 
endobacteria, corroborating the genetic findings. The biological relevance of such extensive rewiring of metabolome remains to be studied [60].

Bacteria isolated from the surface-decontaminated spores of AM fungi, Glomus intraradices and Glomus mosseae, from field rhizospheres samples of Festuca ovina and Leucanthemum vulgare show antifungal characteristics [61]. Transcriptomic analyses studying the interaction between endobacteria and S. indica show the bacteria may produce antibiotics and may be involved in resistance to various antimicrobial compounds [42]. These reports suggest that endobacteria may promote competitive fitness of the fungal host in polymicrobial environments.

\subsection{Fungal Highways for Bacterial Dissemination}

Numerous emerging reports show bacterial movement along hyphae in various niches [62,63], influenced by the physicochemical properties of the microhabitats, in addition to the inherent characteristics of the BFIs [64]. In most cases, bacteria show chemotaxis towards the fungus and employ flagellar-mediated motility for movement, with minor roles for T3 and T4SS. Migration along hyphae can confer competitive fitness advantages $[64,65]$. The contaminant biodegrading bacterium, Pseudomonas putida, showed chemotaxis towards Pythium ultimum (an oomycete but with similar hyphal morphology of fungi), and only moved across airspaces in unsaturated soil when present with the oomycete [66], suggesting that such interactions offer novel solutions to deal with anthropogenic contaminants [67-69]. Serratia sp. move, spread over and kill hyphae of certain fungi. This dispersal mechanism was specific to zygomycetes only, which has been attributed to fungal topography and architecture [17]. Burkholderia spp., Ralstonia spp., Dyella spp., and Sphingobacterium spp. all showed migration on the hyphae of the fungus Lyophyllum sp. Strain Karsten [70]. Burkholderia terrae, that migrates on diverse Asco- and Basidiomycete fungal hosts [71], facilitated the hitch-hiking by Dyella japonicum BS013 on the fungal hyphae [72]. Dispersal of Paraburkholderia terrae on the Lyophyllum sp. was significantly higher at low $\mathrm{pH}$, suggesting that associations with the fungus may have protective roles [73]. Motile Proteobacteria swim on aqueous films formed on fungal hyphae in cheese rinds, altering cheese rind microbiomes preferentially towards motile bacteria [74]. This confirmed the long-standing hypothesis that water films on hyphal surfaces facilitate bacterial movement, as aerial hyphae cannot support bacterial migration [64]. B. subtilis requires its flagella to travel back and forth along the mycelium of $A$. nidulans and promotes hyphal growth through the production of thiamine [62]. With the improvement in microscopic techniques, along with novel in situ methods, many more BFIs in diverse niches are sure to be identified in the near future [75].

\section{Implications of BFIs on Host Health and Disease}

The previous sections of this review have identified mechanisms of bacterial attachment and invasion into fungal structures, as well as demonstrated the impact that these interactions can have on the fitness and dissemination of microbial partners in BFIs. Oftentimes, these BFIs can also impact either their mammalian or plant host through increased virulence resulting in more severe disease outcomes or by promoting environmental changes that positively affect other organisms like plants in the vicinity. Here, we highlight the roles of some BFIs in human and plant health.

\subsection{Humans}

BFIs in human health are a relatively understudied area of research. Much of the focus has been on identifying the microorganisms that are a part of the human normal flora and determining the changes that occur in these populations during disease, a movement that was catalyzed by the NIH Human Microbiome Project [4]. The microbiome of healthy individuals is comprised of bacteria, fungi, and viruses that relay protection by educating the host immune response and microbial competition to limit infection by pathogenic microorganisms. Specific BFIs have been identified in several clinical fields, including oral $[5,7,9,10]$, skin [76], and respiratory health [13]. Other implications of BFIs have been found in clinical conditions like sepsis [77]. Some of the most common BFIs identified in human 
health are either of C. albicans and S. aureus or A. fumigatus and P. aeruginosa, of which there are several reviews that discuss their prevalence and overall impact in clinical settings, in addition to other clinically relevant pairings [78-82]. Additionally, there have been several studies that have been reviewed regarding BFI secreted factors and their implications in growth, virulence, and survival of the microorganisms [82-84]. However, studies focusing on the direct impact of the physical interactions in in vivo disease models are limited. The best studied physical interactions in vivo are of $C$. albicans and S. aureus as described above.

S. aureus is a prime example of the impact of BFIs on the invasion and dissemination of pathogens in mammalian disease. S. aureus is a part of the human normal flora of skin, nares, and gastrointestinal tract, though it can cause disease when the host is immunocompromised. The fungal opportunistic pathogen C. albicans is frequently isolated alongside $S$. aureus forming complex inter-kingdom biofilms on medical equipment and in clinical disorders like cystic fibrosis and bloodstream infections. There have been several studies that have found increased morbidity and mortality when mice are co-inoculated with both organisms [11,77]. In a recent intra-abdominal infection study, $80-100 \%$ of mice infected with both $C$. albicans and S. aureus were deceased within $20 \mathrm{hr}$ post inoculation while individually infected mice did not die in this timeframe. This deadly outcome was attributed to C. albicans inducing increased alpha-toxin by S. aureus [77]. A similar study using an oral infection model also saw increased morbidity and mortality associated when these two organisms were co-inoculated. Though the finding in this study was that $C$. albicans' invasive hyphae are utilized via physical interactions by $S$. aureus to invade and disseminate within the host tissue and bloodstream. If $S$. aureus is unable to bind to the hyphae, it is no longer able to cause an invasive infection [11].

While A. fumigatus and P. aeruginosa have been rarely studied using in vivo systems $[58,85,86]$, in vitro data has demonstrated that P. aeruginosa binds to the surface of A. fumigatus [14]. Clinical and the few in vivo studies available indicate that co-infection with both organisms leads to increased morbidity and mortality $[13,58,85,86]$, much like what is seen with C. albicans and S. aureus $[11,77]$. Another aspect to consider when it comes to studying these organisms in vivo is strain variability. Reece et al. found that death of Galleria mellonella co-infected with A. fumigatus and P. aeruginosa occurs in a strain-dependent manner [58]. As these two organisms are commonly isolated with one another, understanding the relevance of physical interactions between the organisms could prove to be enlightening when it comes to their dissemination in the lung.

Our knowledge of these microbial interactions has become especially important in light of the current global pandemic caused by the severe acute respiratory syndrome coronavirus 2 (SARS-CoV2). There is an increased incidence of Aspergillus sp. and numerous opportunistic bacteria found in the respiratory secretions of individuals that are infected with SARS-CoV2 [87-89]. The risk of developing secondary infections caused by these microorganisms is likely confounded by patients being placed on ventilator support [88]. As we have discussed in previous sections, interactions between bacteria and fungi can result in changes in susceptibility to antibiotics and altered virulence of the organisms. Because there is so little known about SARS-CoV2, we do not currently know what impact that the polymicrobial environment has on the viral response to therapeutics and disease progression. Therefore, study of the virus with other microorganisms should be considered for future research directions.

\subsection{Plants}

As microbes co-exist in the rhizosphere, they form intimate associations with each other bearing consequences for microbial community structure, which in turn influences plant health. Furthermore, as discussed in Section 3.1, bacterial partners can finely tune sporulation, thus altering dissemination of infection propagules, vertical transmission of endofungal bacteria in fungal spores' aids in their long-distance dispersal, and reprogramming of secondary metabolism results in production of compounds which exacerbate disease development.

'Biocontrol' of plant pathogens by utilizing antagonistic microbes that act via antibiosis or direct competition have been very well studied. Perhaps the most famous are the application of $P$. fluorescens 
and Trichoderma viridae. Although biocontrol effects can be clearly identified in vitro, it often fails to provide results in natural settings. These have been thoroughly reviewed $[90,91]$ and will not be discussed here.

In many cases, co-infection results in increased disease severity. One of the earliest reports is of natural field isolates of bacteria associated with Stagonospora nodorum, contributing to the increased pathogenicity of the fungus, the causal agent of wheat blotch disease [92]. As discussed earlier, in the famous interaction between M. rhizoxinica and R. microsporus, rhizoxin production by the bacterium is required for fungal pathogenicity [3]. Bacterial isolates that were co-isolated with Rhizoctonia solani, a notorious root rotter were reported to adopt endohyphal behavior in vitro, with a change in morphology associated with the intracellular lifestyle. Colonization of the fungus by these bacteria, belonging to the genus Enterobacter, was required for full virulence of the fungus on creeping bentgrass [93]. Co-inoculation of tomato plants with S. indica and Trinickia sp. T12-10 showed a significant reduction in disease when challenged with the plant wilt pathogen Fusarium oxysporum and showed a significantly higher mitigation from disease when infected with Rhizoctonia solani [24]. Burkholderia glumae and Fusarium graminearum frequently co-isolated from infected rice grains showed physical attachment in in vitro assays. Co-infection of rice seedlings showed an increase in disease severity and deoxynivalenol production, which is a virulence factor for F. graminearum [44]. Deoxynivalenol, also called vomit toxin, can cause acute vomiting, abdominal pain, and fever [94]. Thus, this BFI not only increases yield loss threatening food security, but also threatens food safety.

On the contrary, certain BFIs also promote nutrient acquisition by facilitating plant associations with mycorrhizal fungi and nitrogen fixing bacteria to boost plant health. In addition to protection from disease, BFIs between plant-helper microbes enhance plant growth. S. indica is a plant endophyte known for its plant protecting roles. Addition of Trinickia sp. T12-10 to S. indica inoculated tomato plants resulted in enhanced fungal colonization of plant roots [24]. Successful endofungal symbiosis between $R$. radiobacter and $S$. indica has been shown to be vital for effective plant growth promotion and systemic resistance against powdery mildew infection in barley [19]. A microscopic analysis by Paul et al. suggests that the basidiomycete yeast endophyte Rhodotorula mucilaginosa, in its filamentous form, hosts Pseudomonas stutzeri as an endofungal diazotroph. This association is reported to enable the fungus to fix nitrogen and grow in N-deplete conditions. The bacterial dinitrogen reductase required to convert atmospheric dinitrogen gas into ammonia was transcribed by the fungus under adequate N. Co-inoculation of rice plants with both partners was shown to promote plant growth and plant nitrogen nutrition [95]. Interaction between $\mathrm{CaGg}$ and G. margarita promotes fungal response to strigalactones, which are plant small molecules that stimulate branching and establishment of AMF symbioses [27]. MHB are mycorrhizal helper bacteria defined as bacteria that positively interact with established symbiosis between mycorrhizal fungi and plants, or mycorrhization helper bacteria that facilitate symbiosis between mycorrhizal fungi and plants [46]. They primarily function by stimulating fungal growth and enhancing contact between the fungi and plants. Numerous reports of MHB isolation, identification, and studies on their consequences exist [49-53]. The roles of MHB in symbiosis, their effects on arbuscular mycorrhizal or ectomycorrhizal host, and their specificities and mechanisms have been studied for decades and have been reviewed extensively elsewhere [46-48]. Such tri-partite interactions help promote plant growth as well as stress tolerance $[47,54-56]$.

\section{Conclusions}

As the field of bacterial-fungal interactions grows, we begin to understand the implications that these interactions have not only on the microorganisms, but also on plant and human hosts. This review shows that there are several areas of overlapping commonalities between BFIs in agriculture and clinical settings, including the use of fungal structures for bacterial dispersal $[11,62,63,73]$, using ECM for bacterial attachment [14,18], and developmental changes that can occur in both fungi and bacteria [43,49] (Figure 2). It is possible that there are even more commonalities that have yet to be discovered, 
including endosymbiosis in clinical settings. While we focus mainly on the microorganisms involved in these interactions for this review, we would be remiss if we did not mention the potential impact that the host and the niche-specific environmental factors, can have on these interactions as well. Environmental factors include but are not limited to temperature, $\mathrm{pH}$, nutrients, and oxygen levels in the specific niches. These undoubtedly contribute to physical interactions between bacteria and fungi. Comparing and contrasting aspects of microbial interactions in the context of the environment during plant, animal and human hosts interactions would provide a more complete understanding of the mechanisms that facilitate BFI establishment.

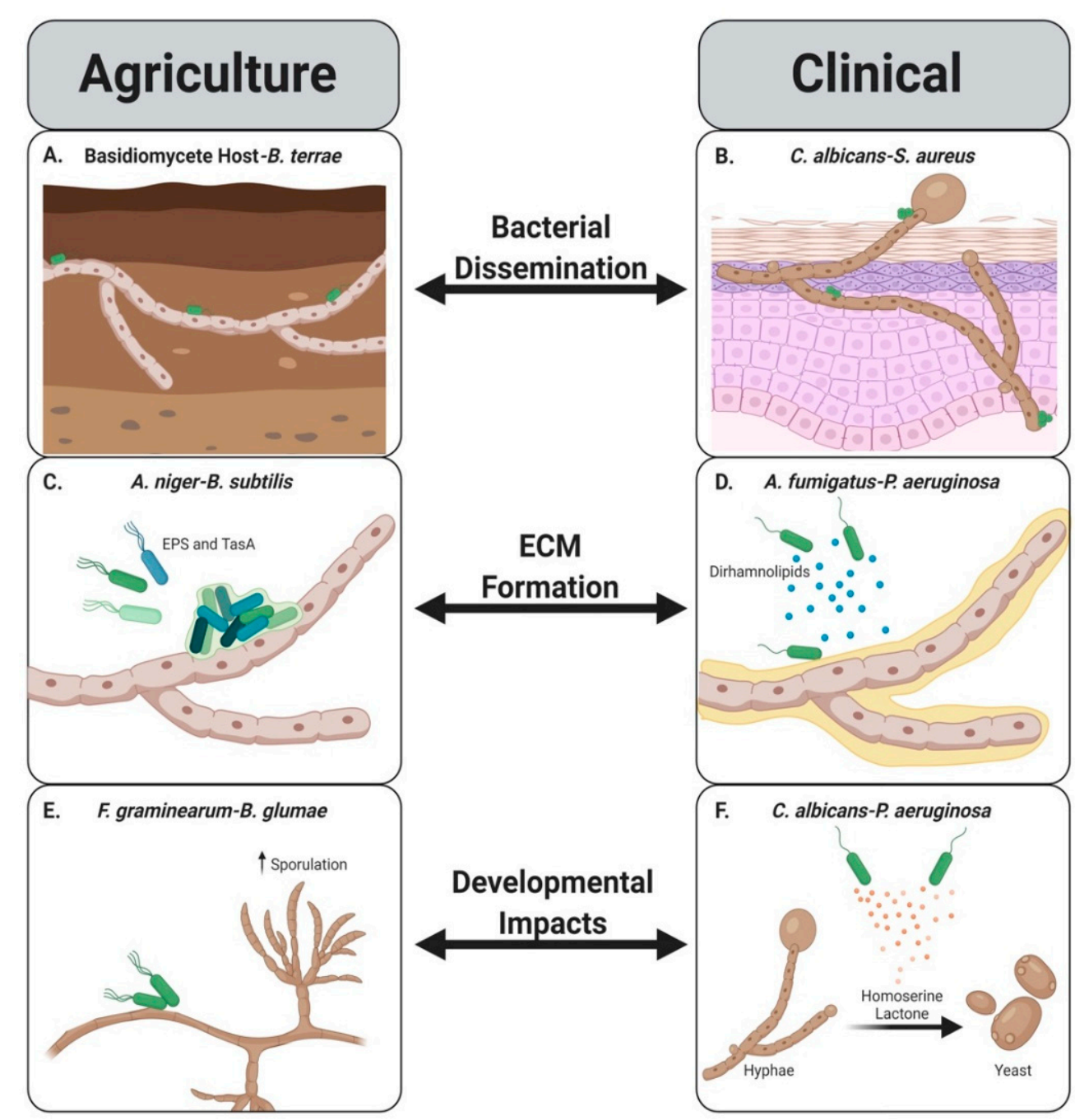

Figure 2. Common outcomes of BFIs in agriculture and clinical systems. Bacteria (green) travel along fungal hyphae $(\tan )(\mathbf{A}, \mathbf{B})$ resulting in their dissemination. The ECM produced by bacteria $((\mathbf{C})$-green, EPS and TasA) or induced ECM (yellow) by bacterial mediators ((D)_Blue, dirhamnolipids) mediates bacterial binding to the fungal organisms $(\tan )(\mathbf{C}, \mathbf{D})$. Developmental changes occur in fungi (tan) upon interaction with bacteria (green) (E,F). Created with BioRender.com.

While there have been great strides to understanding these interactions in the agricultural setting with model organisms like AM-fungi, clinical settings are still in the initial stages of this research [96]. As many microorganisms in the agricultural setting also have clinical significance, we can begin to reconcile agricultural findings with clinical research. This is especially important now as we begin to explore novel SARS-CoV2 and its interaction with polymicrobial communities in the lung that are made up of bacterial and fungal organisms [97]. 
Author Contributions: B.N.S., N.V., and N.P.K. contributed equally in the conception, design, writing, review and editing of this work. All authors have read and agreed to the published version of the manuscript.

Funding: This review was funded in part by the National Institutes of Health R56 AI150669-01 and the National Institute of Food and Agriculture, United States Department of Agriculture, Hatch project 1012878 to N.P.K., the NIH T32 ES007015 to B.N.S. and the UW-Madison Food Research Institute's E. Michael and Winona Foster Wisconsin Distinguished Fellowship Award to N.V.

Acknowledgments: We would like to thank Saima Khalid for her kind review of this manuscript.

Conflicts of Interest: The authors declare no conflict of interest.

\section{References}

1. Bianciotto, V.; Bandi, C.; Minerdi, D.; Sironi, M.; Tichy, H.V.; Bonfante, P. An obligately endosymbiotic mycorrhizal fungus itself harbors obligately intracellular bacteria. Appl. Environ. Microbiol. 1996, 62, 3005-3010. [CrossRef] [PubMed]

2. Estrada-de Los Santos, P.; Palmer, M.; Chávez-Ramírez, B.; Beukes, C.; Steenkamp, E.T.; Briscoe, L.; Khan, N.; Maluk, M.; Lafos, M.; Humm, E.; et al. Whole genome analyses suggests that Burkholderia sensu lato contains two additional novel genera (Mycetohabitans gen. nov., and Trinickia gen. nov.): Implications for the evolution of diazotrophy and nodulation in the Burkholderiaceae. Genes 2018, 9, 389. [CrossRef] [PubMed]

3. Partida-Martinez, L.P.; Hertweck, C. Pathogenic fungus harbours endosymbiotic bacteria for toxin production. Nature 2005, 437, 884-888. [CrossRef] [PubMed]

4. Turnbaugh, P.J.; Ley, R.E.; Hamady, M.; Fraser-Liggett, C.M.; Knight, R.; Gordon, J.I. The Human Microbiome Project. Nature 2007, 449, 804-810. [CrossRef]

5. Ovchinnikova, E.S.; Krom, B.P.; Harapanahalli, A.K.; Busscher, H.J.; van der Mei, H.C. Surface thermodynamic and adhesion force evaluation of the role of chitin-binding protein in the physical interaction between Pseudomonas aeruginosa and Candida albicans. Langmuir ACS J. Surf. Colloids 2013, 29, 4823-4829. [CrossRef] [PubMed]

6. Ovchinnikova, E.S.; Krom, B.P.; van der Mei, H.C.; Busscher, H.J. Force microscopic and thermodynamic analysis of the adhesion between Pseudomonas aeruginosa and Candida albicans. Soft Matter 2012, 8, 6454-6461. [CrossRef]

7. Ovchinnikova, E.S.; Krom, B.P.; Busscher, H.J.; van der Mei, H.C. Evaluation of adhesion forces of Staphylococcus aureus along the length of Candida albicans hyphae. BMC Microbiol. 2012, 12, 281. [CrossRef]

8. Beaussart, A.; Herman, P.; El-Kirat-Chatel, S.; Lipke, P.N.; Kucharíková, S.; Van Dijck, P.; Dufrêne, Y.F. Single-cell force spectroscopy of the medically important Staphylococcus epidermidis-Candida albicans interaction. Nanoscale 2013, 5, 10894-10900. [CrossRef]

9. Silverman, R.J.; Nobbs, A.H.; Vickerman, M.M.; Barbour, M.E.; Jenkinson, H.F. Interaction of Candida albicans cell wall Als3 protein with Streptococcus gordonii SspB adhesin promotes development of mixed-species communities. Infect. Immun. 2010, 78, 4644. [CrossRef]

10. Peters, B.M.; Ovchinnikova, E.S.; Krom, B.P.; Schlecht, L.M.; Zhou, H.; Hoyer, L.L.; Busscher, H.J.; van der Mei, H.C.; Jabra-Rizk, M.A.; Shirtliff, M.E. Staphylococcus aureus adherence to Candida albicans hyphae is mediated by the hyphal adhesin Als3p. Microbiology (Read. Engl.) 2012, 158, 2975-2986. [CrossRef]

11. Schlecht, L.M.; Peters, B.M.; Krom, B.P.; Freiberg, J.A.; Hänsch, G.M.; Filler, S.G.; Jabra-Rizk, M.A.; Shirtliff, M.E. Systemic Staphylococcus aureus infection mediated by Candida albicans hyphal invasion of mucosal tissue. Microbiology (Read. Engl.) 2015, 161, 168-181. [CrossRef] [PubMed]

12. Hoyer, L.L.; Payne, T.L.; Bell, M.; Myers, A.M.; Scherer, S. Candida albicans ALS3 and insights into the nature of the ALS gene family. Curr. Genet. 1998, 33, 451-459. [CrossRef] [PubMed]

13. Reece, E.; Segurado, R.; Jackson, A.; McClean, S.; Renwick, J.; Greally, P. Co-colonisation with Aspergillus fumigatus and Pseudomonas aeruginosa is associated with poorer health in cystic fibrosis patients: An Irish registry analysis. BMC Pulm. Med. 2017, 17, 70. [CrossRef] [PubMed]

14. Briard, B.; Rasoldier, V.; Bomme, P.; ElAouad, N.; Guerreiro, C.; Chassagne, P.; Muszkieta, L.; Latgé, J.-P.; Mulard, L.; Beauvais, A. Dirhamnolipids secreted from Pseudomonas aeruginosa modify anjpegungal susceptibility of Aspergillus fumigatus by inhibiting $\beta 1,3$ glucan synthase activity. ISME J. 2017, 11, 1578-1591. [CrossRef] 
15. Harriott, M.M.; Noverr, M.C. Candida albicans and Staphylococcus aureus form polymicrobial biofilms: Effects on antimicrobial resistance. Antimicrob. Agents Chemother. 2009, 53, 3914-3922. [CrossRef]

16. Toljander, J.F.; Artursson, V.; Paul, L.R.; Jansson, J.K.; Finlay, R.D. Attachment of different soil bacteria to arbuscular mycorrhizal fungal extraradical hyphae is determined by hyphal vitality and fungal species. FEMS Microbiol. Lett. 2006, 254, 34-40. [CrossRef]

17. Hover, T.; Maya, T.; Ron, S.; Sandovsky, H.; Shadkchan, Y.; Kijner, N.; Mitiagin, Y.; Fichtman, B.; Harel, A.; Shanks, R.M.; et al. Mechanisms of bacterial (Serratia marcescens) attachment to, migration along, and killing of fungal hyphae. Appl. Environ. Microbiol. 2016, 82, 2585-2594. [CrossRef]

18. Kjeldgaard, B.; Listian, S.A.; Ramaswamhi, V.; Richter, A.; Kiesewalter, H.T.; Kovács, Á.T. Fungal hyphae colonization by Bacillus subtilis relies on biofilm matrix components. Biofilm 2019, 1, 100007. [CrossRef]

19. Mosse, B. Honey-coloured, sessile endogone spores-III. Wall structure. Arch. Microbiol. 1970, 74, 146-159. [CrossRef]

20. Spatafora, J.W.; Chang, Y.; Benny, G.L.; Lazarus, K.; Smith, M.E.; Berbee, M.L.; Bonito, G.; Corradi, N.; Grigoriev, I.; Gryganskyi, A.; et al. A phylum-level phylogenetic classification of zygomycete fungi based on genome-scale data. Mycologia 2016, 108, 1028-1046. [CrossRef]

21. Bonfante, P.; Venice, F. Mucoromycota: Going to the roots of plant-interacting fungi. Fungal Biol. Rev. 2020, 34, 100-113. [CrossRef]

22. Partida-Martinez, L.P.; Groth, I.; Schmitt, I.; Richter, W.; Roth, M.; Hertweck, C. Burkholderia rhizoxinica sp. nov. and Burkholderia endofungorum sp. nov., bacterial endosymbionts of the plant-pathogenic fungus Rhizopus microsporus. Int. J. Syst. Evol. Microbiol. 2007, 57, 2583-2590. [CrossRef] [PubMed]

23. Moebius, N.; Üzüm, Z.; Dijksterhuis, J.; Lackner, G.; Hertweck, C. Active invasion of bacteria into living fungal cells. eLife 2014, 3, e03007. [CrossRef]

24. Lackner, G.; Moebius, N.; Partida-Martinez, L.P.; Boland, S.; Hertweck, C. Evolution of an endofungal lifestyle: Deductions from the Burkholderia rhizoxinica genome. BMC Genom. 2011, 12, 210. [CrossRef] [PubMed]

25. Niehs, S.P.; Scherlach, K.; Hertweck, C. Genomics-driven discovery of a linear lipopeptide promoting host colonization by endofungal bacteria. Org. Biomol. Chem. 2018, 16, 8345-8352. [CrossRef]

26. Lackner, G.; Moebius, N.; Hertweck, C. Endofungal bacterium controls its host by an hrp type III secretion system. ISME J. 2011, 5, 252-261. [CrossRef]

27. Richter, I.; Uzum, Z.; Stanley, C.E.; Moebius, N.; Stinear, T.P.; Pidot, S.J.; Ferling, I.; Hillmann, F.; Hertweck, C. Secreted TAL effectors protect symbiotic bacteria from entrapment within fungal hyphae. bioRxiv 2020. [CrossRef]

28. Carter, M.E.; Carpenter, S.C.D.; Dubrow, Z.E.; Sabol, M.R.; Rinaldi, F.C.; Lastovestsky, O.A.; Mondo, S.J.; Pawlowska, T.E.; Bogdanove, A.J. A TAL effector-like protein of symbiotic Mycetohabitans increases stress tolerance and alters the transcriptome of the fungal host Rhizopus microsporus. bioRxiv 2020. [CrossRef]

29. Desirò, A.; Salvioli, A.; Ngonkeu, E.L.; Mondo, S.J.; Epis, S.; Faccio, A.; Kaech, A.; Pawlowska, T.E.; Bonfante, P. Detection of a novel intracellular microbiome hosted in arbuscular mycorrhizal fungi. ISME J. 2014, 8, 257-270. [CrossRef]

30. Naumann, M.; Schüßler, A.; Bonfante, P. The obligate endobacteria of arbuscular mycorrhizal fungi are ancient heritable components related to the Mollicutes. ISME J. 2010, 4, 862-871. [CrossRef]

31. Bianciotto, V.; Genre, A.; Jargeat, P.; Lumini, E.; Bécard, G.; Bonfante, P. Vertical transmission of endobacteria in the arbuscular mycorrhizal fungus Gigaspora margarita through generation of vegetative spores. Appl. Environ. Microbiol. 2004, 70, 3600. [CrossRef] [PubMed]

32. Ghignone, S.; Salvioli, A.; Anca, I.; Lumini, E.; Ortu, G.; Petiti, L.; Cruveiller, S.; Bianciotto, V.; Piffanelli, P.; Lanfranco, L.; et al. The genome of the obligate endobacterium of an AM fungus reveals an interphylum network of nutritional interactions. ISME J. 2012, 6, 136-145. [CrossRef] [PubMed]

33. Ruiz-Lozano, J.M.; Bonfante, P. A Burkholderia strain living inside the arbuscular mycorrhizal fungus Gigaspora margarita possesses the $v a c B$ Gene, which is involved in host cell colonization by bacteria. Microb. Ecol. 2000, 39, 137-144. [CrossRef] [PubMed]

34. Ohshima, S.; Sato, Y.; Fujimura, R.; Takashima, Y.; Hamada, M.; Nishizawa, T.; Narisawa, K.; Ohta, H. Mycoavidus cysteinexigens gen. nov., sp. nov., an endohyphal bacterium isolated from a soil isolate of the fungus Mortierella elongata. Int. J. Syst. Evol. Microbiol. 2016, 66, 2052-2057. [CrossRef] 
35. Li, Z.; Yao, Q.; Dearth, S.P.; Entler, M.R.; Castro Gonzalez, H.F.; Uehling, J.K.; Vilgalys, R.J.; Hurst, G.B.; Campagna, S.R.; Labbé, J.L.; et al. Integrated proteomics and metabolomics suggests symbiotic metabolism and multimodal regulation in a fungal-endobacterial system. Environ. Microbiol. 2017, 19, 1041-1053. [CrossRef]

36. Sharmin, D.; Guo, Y.; Nishizawa, T.; Ohshima, S.; Sato, Y.; Takashima, Y.; Narisawa, K.; Ohta, H. Comparative genomic insights into endofungal lifestyles of two bacterial endosymbionts, Mycoavidus cysteinexigens and Burkholderia rhizoxinica. Microbes Environ. 2018, 33, 66-76. [CrossRef]

37. Guo, H.; Glaeser, S.P.; Alabid, I.; Imani, J.; Haghighi, H.; Kämpfer, P.; Kogel, K.H. The abundance of endofungal bacterium Rhizobium radiobacter (syn. Agrobacterium tumefaciens) increases in its fungal host Piriformospora indica during the Tripartite Sebacinalean Symbiosis with higher plants. Front. Microbiol. 2017, 8, 629. [CrossRef]

38. Baltrus, D.A.; Dougherty, K.; Arendt, K.R.; Huntemann, M.; Clum, A.; Pillay, M.; Palaniappan, K.; Varghese, N.; Mikhailova, N.; Stamatis, D.; et al. Absence of genome reduction in diverse, facultative endohyphal bacteria. Microb. Genom. 2017, 3, e000101. [CrossRef]

39. Hoffman, M.T.; Arnold, A.E. Diverse bacteria inhabit living hyphae of phylogenetically diverse fungal endophytes. Appl. Environ. Microbiol. 2010, 76, 4063-4075. [CrossRef]

40. Spraker, J.E.; Sanchez, L.M.; Lowe, T.M.; Dorrestein, P.C.; Keller, N.P. Ralstonia solanacearum lipopeptide induces chlamydospore development in fungi and facilitates bacterial entry into fungal tissues. ISME J. 2016, 10, 2317-2330. [CrossRef]

41. Hazarika, D.J.; Gautom, T.; Parveen, A.; Goswami, G.; Barooah, M.; Modi, M.K.; Boro, R.C. Mechanism of interaction of an endofungal bacterium Serratia marcescens D1 with its host and non-host fungi. PLoS ONE 2020, 15, e0224051. [CrossRef] [PubMed]

42. Duque, A.; Samad, A.; Nybroe, O.; Antonielli, L.; Sessitsch, A.; Compant, S. Interaction between endophytic Proteobacteria strains and Serendipita indica enhances biocontrol activity against fungal pathogens. Plant Soil 2020. [CrossRef]

43. Pent, M.; Bahram, M.; Põldmaa, K. Fruitbody chemistry underlies the structure of endofungal bacterial communities across fungal guilds and phylogenetic groups. ISME J. 2020, 14, 2131-2141. [CrossRef] [PubMed]

44. Partida-Martínez, L.P. The fungal holobiont: Evidence from early diverging fungi. Environ. Microbiol. 2017, 19, 2919-2923. [CrossRef]

45. Briard, B.; Bomme, P.; Lechner, B.E.; Mislin, G.L.A.; Lair, V.; Prévost, M.-C.; Latgé, J.-P.; Haas, H.; Beauvais, A. Pseudomonas aeruginosa manipulates redox and iron homeostasis of its microbiota partner Aspergillus fumigatus via phenazines. Sci. Rep. 2015, 5, 8220. [CrossRef]

46. Mowat, E.; Rajendran, R.; Williams, C.; McCulloch, E.; Jones, B.; Lang, S.; Ramage, G. Pseudomonas aeruginosa and their small diffusible extracellular molecules inhibit Aspergillus fumigatus biofilm formation. FEMS Microbiol. Lett. 2010, 313, 96-102. [CrossRef]

47. Briard, B.; Heddergott, C.; Latgé, J.-P. Volatile compounds emitted by Pseudomonas aeruginosa stimulate growth of the fungal pathogen Aspergillus fumigatus. mBio 2016, 7, e00219-16. [CrossRef]

48. Margalit, A.; Carolan, J.C.; Shehan, D.; Kavanagh, K. The Aspergillus fumigatus secretome alters the proteome of Pseudomonas aeruginosa to stimulate bacterial growth: Implications for co-infection. Mol. Cell. Proteom. 2020. [CrossRef]

49. Hogan, D.A.; Vik, Å.; Kolter, R. A Pseudomonas aeruginosa quorum-sensing molecule influences Candida albicans morphology. Mol. Microbiol. 2004, 54, 1212-1223. [CrossRef] [PubMed]

50. Partida-Martinez, L.P.; Monajembashi, S.; Greulich, K.O.; Hertweck, C. Endosymbiont-dependent host reproduction maintains bacterial-fungal mutualism. Curr. Biol. CB 2007, 17, 773-777. [CrossRef]

51. Hansen, T.K.; Jakobsen, M. Possible role of microbial interactions for growth and sporulation of Penicillium roqueforti in Danablu. Lait 1997, 77, 479-488. [CrossRef]

52. Adams, A.S.; Currie, C.R.; Cardoza, Y.; Klepzig, K.D.; Raffa, K.F. Effects of symbiotic bacteria and tree chemistry on the growth and reproduction of bark beetle fungal symbionts. Can. J. For. Res. 2009, 39, 1133-1147. [CrossRef]

53. Deveau, A.; Palin, B.; Delaruelle, C.; Peter, M.; Kohler, A.; Pierrat, J.C.; Sarniguet, A.; Garbaye, J.; Martin, F.; Frey-Klett, P. The mycorrhiza helper Pseudomonas fluorescens BBc6R8 has a specific priming effect on the growth, morphology and gene expression of the ectomycorrhizal fungus Laccaria bicolor S238N. New Phytol. 2007, 175, 743-755. [CrossRef] 
54. Frey-Klett, P.; Burlinson, P.; Deveau, A.; Barret, M.; Tarkka, M.; Sarniguet, A. Bacterial-fungal interactions: Hyphens between agricultural, clinical, environmental, and food microbiologists. Microbiol. Mol. Biol. Rev. MMBR 2011, 75, 583-609. [CrossRef] [PubMed]

55. Long, L.; Lin, Q.; Yao, Q.; Zhu, H. Population and function analysis of cultivable bacteria associated with spores of arbuscular mycorrhizal fungus. Gigaspora Margarita 2017, 7, 8. [CrossRef] [PubMed]

56. Hildebrandt, U.; Ouziad, F.; Marner, F.J.; Bothe, H. The bacterium Paenibacillus validus stimulates growth of the arbuscular mycorrhizal fungus Glomus intraradices up to the formation of fertile spores. FEMS Microbiol. Lett. 2006, 254, 258-267. [CrossRef]

57. Venkatesh, N.; Keller, N.P. Mycotoxins in conversation with bacteria and fungi. Front. Microbiol. 2019, 10, 403. [CrossRef]

58. Reece, E.; Doyle, S.; Greally, P.; Renwick, J.; McClean, S. Aspergillus fumigatus inhibits Pseudomonas aeruginosa in co-culture: Implications of a mutually antagonistic relationship on virulence and inflammation in the CF airway. Front. Microbiol. 2018, 9. [CrossRef]

59. Salvioli, A.; Ghignone, S.; Novero, M.; Navazio, L.; Venice, F.; Bagnaresi, P.; Bonfante, P. Symbiosis with an endobacterium increases the fitness of a mycorrhizal fungus, raising its bioenergetic potential. ISME J. 2016, 10, 130-144. [CrossRef]

60. Dearth, S.P.; Castro, H.F.; Venice, F.; Tague, E.D.; Novero, M.; Bonfante, P.; Campagna, S.R. Metabolome changes are induced in the arbuscular mycorrhizal fungus Gigaspora margarita by germination and by its bacterial endosymbiont. Mycorrhiza 2018, 28, 421-433. [CrossRef]

61. Bharadwaj, D.P.; Lundquist, P.-O.; Persson, P.; Alström, S. Evidence for specificity of cultivable bacteria associated with arbuscular mycorrhizal fungal spores. FEMS Microbiol. Ecol. 2008, 65, 310-322. [CrossRef] [PubMed]

62. Abeysinghe, G.; Kuchira, M.; Kudo, G.; Masuo, S.; Ninomiya, A.; Takahashi, K.; Utada, A.S.; Hagiwara, D.; Nomura, N.; Takaya, N.; et al. Fungal mycelia and bacterial thiamine establish a mutualistic growth mechanism. bioRxiv 2020. [CrossRef]

63. Bravo, D.; Cailleau, G.; Bindschedler, S.; Simon, A.; Job, D.; Verrecchia, E.; Junier, P. Isolation of oxalotrophic bacteria able to disperse on fungal mycelium. FEMS Microbiol. Lett. 2013, 348, 157-166. [CrossRef]

64. Yang, P.; van Elsas, J.D. Mechanisms and ecological implications of the movement of bacteria in soil. Appl. Soil Ecol. 2018, 129, 112-120. [CrossRef]

65. Pion, M.; Bshary, R.; Bindschedler, S.; Filippidou, S.; Wick, L.Y.; Job, D.; Junier, P. Gains of bacterial flagellar motility in a fungal world. Appl. Environ. Microbiol. 2013, 79, 6862. [CrossRef] [PubMed]

66. Furuno, S.; Päzolt, K.; Rabe, C.; Neu, T.R.; Harms, H.; Wick, L.Y. Fungal mycelia allow chemotactic dispersal of polycyclic aromatic hydrocarbon-degrading bacteria in water-unsaturated systems. Environ. Microbiol. 2010, 12, 1391-1398. [CrossRef]

67. Banitz, T.; Frank, K.; Wick, L.Y.; Harms, H.; Johst, K. Spatial metrics as indicators of biodegradation benefits from bacterial dispersal networks. Ecol. Indic. 2016, 60, 54-63. [CrossRef]

68. Worrich, A.; König, S.; Miltner, A.; Banitz, T.; Centler, F.; Frank, K.; Thullner, M.; Harms, H.; Kästner, M.; Wick, L.Y. Mycelium-like networks increase bacterial dispersal, growth, and biodegradation in a model ecosystem at various water potentials. Appl. Environ. Microbiol. 2016, 82, 2902. [CrossRef]

69. Kohlmeier, S.; Smits, T.H.; Ford, R.M.; Keel, C.; Harms, H.; Wick, L.Y. Taking the fungal highway: Mobilization of pollutant-degrading bacteria by fungi. Environ. Sci. Technol. 2005, 39, 4640-4646. [CrossRef]

70. Warmink, J.A.; van Elsas, J.D. Migratory response of soil bacteria to Lyophyllum sp. strain Karsten in soil microcosms. Appl. Environ. Microbiol. 2009, 75, 2820-2830. [CrossRef]

71. Nazir, R.; Tazetdinova, D.I.; van Elsas, J.D. Burkholderia terrae BS001 migrates proficiently with diverse fungal hosts through soil and provides protection from antifungal agents. Front. Microbiol. 2014, 5. [CrossRef]

72. Warmink, J.A.; Nazir, R.; Corten, B.; van Elsas, J.D. Hitchhikers on the fungal highway: The helper effect for bacterial migration via fungal hyphae. Soil Biol. Biochem. 2011, 43, 760-765. [CrossRef]

73. Yang, P.; da Rocha Calixto, R.O.; van Elsas, J.D. Migration of Paraburkholderia terrae BS001 along old fungal hyphae in soil at various $\mathrm{pH}$ levels. Microb. Ecol. 2018, 76, 443-452. [CrossRef] [PubMed] 
74. Zhang, Y.; Kastman, E.K.; Guasto, J.S.; Wolfe, B.E. Fungal networks shape dynamics of bacterial dispersal and community assembly in cheese rind microbiomes. Nat. Commun. 2018, 9, 336. [CrossRef]

75. Simon, A.; Bindschedler, S.; Job, D.; Wick, L.Y.; Filippidou, S.; Kooli, W.M.; Verrecchia, E.P.; Junier, P. Exploiting the fungal highway: Development of a novel tool for the in situ isolation of bacteria migrating along fungal mycelium. FEMS Microbiol. Ecol. 2015, 91. [CrossRef]

76. Kalan, L.; Loesche, M.; Hodkinson, B.P.; Heilmann, K.; Ruthel, G.; Gardner, S.E.; Grice, E.A. Redefining the chronic-wound microbiome: Fungal communities are prevalent, dynamic, and associated with delayed healing. mBio 2016, 7, e01058-16. [CrossRef] [PubMed]

77. Todd, O.A.; Noverr, M.C.; Peters, B.M. Candida albicans impacts Staphylococcus aureus alpha-toxin production via extracellular alkalinization. mSphere 2019, 4, e00780-19. [CrossRef]

78. Zhao, J.; Cheng, W.; He, X.; Liu, Y. The co-colonization prevalence of Pseudomonas aeruginosa and Aspergillus fumigatus in cystic fibrosis: A systematic review and meta-analysis. Microb. Pathog. 2018, 125, 122-128. [CrossRef]

79. Carolus, H.; Van Dyck, K.; Van Dijck, P. Candida albicans and Staphylococcus species: A threatening twosome. Front. Microbiol. 2019, 10. [CrossRef]

80. Krüger, W.; Vielreicher, S.; Kapitan, M.; Jacobsen, I.D.; Niemiec, M.J. Fungal-bacterial interactions in health and disease. Pathogens 2019, 8, 70. [CrossRef]

81. Diaz, P.I.; Strausbaugh, L.D.; Dongari-Bagtzoglou, A. Fungal-bacterial interactions and their relevance to oral health: Linking the clinic and the bench. Front. Cell. Infect. Microbiol. 2014, 4. [CrossRef] [PubMed]

82. Peleg, A.Y.; Hogan, D.A.; Mylonakis, E. Medically important bacterial-fungal interactions. Nat. Rev. Microbiol. 2010, 8, 340-349. [CrossRef] [PubMed]

83. De Sordi, L.; Mühlschlegel, F.A. Quorum sensing and fungal-bacterial interactions in Candida albicans: A communicative network regulating microbial coexistence and virulence. FEMS Yeast Res. 2009, 9, 990-999. [CrossRef] [PubMed]

84. Briard, B.; Mislin, G.L.A.; Latgé, J.-P.; Beauvais, A. Interactions between Aspergillus fumigatus and pulmonary bacteria: Current state of the field, new data, and future perspective. J. Fungi 2019, 5, 48. [CrossRef]

85. Yonezawa, M.; Sugiyama, H.; Kizawa, K.; Hori, R.; Mitsuyama, J.; Araki, H.; Shimakura, M.; Minami, S.; Watanabe, Y.; Yamaguchi, K. A new model of pulmonary superinfection with Aspergillus fumigatus and Pseudomonas aeruginosa in mice. J. Infect. Chemother. Off. J. Jpn. Soc. Chemother. 2000, 6, 155-161. [CrossRef]

86. Mitsuyama, J.; Kizawa, K.; Minami, S.; Watanabe, Y.; Yamaguchi, K. Evaluation of antimicrobial agents using an experimental pulmonary superinfection model with Aspergillus fumigatus and Pseudomonas aeruginosa in leukopenic mice. J. Infect. Chemother. Off. J. Jpn. Soc. Chemother. 2003, 9, 144-150. [CrossRef]

87. Sharma, A.; Hofmeyr, A.; Bansal, A.; Thakkar, D.; Lam, L.; Harrington, Z.; Bhonagiri, D. COVID-19 associated pulmonary aspergillosis (CAPA): An Australian case report. Med. Mycol. Case Rep. 2020. [CrossRef]

88. Fernandez, N.B.; Caceres, D.H.; Beer, K.D.; Irrazabal, C.; Delgado, G.; Farias, L.; Chiller, T.M.; Verweij, P.E.; Stecher, D. Ventilator-associated pneumonia involving Aspergillus flavus in a patient with coronavirus disease 2019 (COVID-19) from Argentina. Med. Mycol. Case Rep. 2020. [CrossRef]

89. Koehler, P.; Cornely, O.A.; Böttiger, B.W.; Dusse, F.; Eichenauer, D.A.; Fuchs, F.; Hallek, M.; Jung, N.; Klein, F.; Persigehl, T.; et al. COVID-19 associated pulmonary aspergillosis. Mycoses 2020, 63, 528-534. [CrossRef]

90. Whipps, J.M. Microbial interactions and biocontrol in the rhizosphere. J. Exp. Bot. 2001, 52, 487-511. [CrossRef]

91. Eljounaidi, K.; Lee, S.K.; Bae, H. Bacterial endophytes as potential biocontrol agents of vascular wilt diseases-Review and future prospects. Biol. Control. 2016, 103, 62-68. [CrossRef]

92. Dewey, F.M.; Wong, Y.L.; Seery, R.; Hollins, T.W.; Gurr, S.J. Bacteria associated with Stagonospora (Septoria) nodorum increase pathogenicity of the fungus. New Phytol. 1999, 144, 489-497. [CrossRef]

93. Obasa, K.; White, F.F.; Fellers, J.; Kennelly, M.; Liu, S.; Katz, B.; Tomich, J.; Moore, D.; Shinogle, H.; Kelley, K. A dimorphic and virulence-enhancing endosymbiont bacterium discovered in Rhizoctonia solani. Phytobiomes J. 2017, 1, 14-23. [CrossRef]

94. Sobrova, P.; Adam, V.; Vasatkova, A.; Beklova, M.; Zeman, L.; Kizek, R. Deoxynivalenol and its toxicity. Interdiscip. Toxicol. 2010, 3, 94-99. [CrossRef] [PubMed]

95. Paul, K.; Saha, C.; Nag, M.; Mandal, D.; Naiya, H.; Sen, D.; Mitra, S.; Kumar, M.; Bose, D.; Mukherjee, G.; et al. A Tripartite Interaction among the Basidiomycete Rhodotorula mucilaginosa-fixing endobacteria, and rice improves plant nitrogen nutrition. Plant Cell 2020, 32, 486. [CrossRef] [PubMed] 
96. Stewart, D.; Romo, J.A.; Lamendella, R.; Kumamoto, C.A. The role of fungi in C. difficile infection: An underappreciated transkingdom interaction. Fungal Genet. Biol. 2019, 129, 1-6. [CrossRef] [PubMed]

97. Calcagno, A.; Ghisetti, V.; Burdino, E.; Trunfio, M.; Allice, T.; Boglione, L.; Bonora, S.; Di Perri, G. Co-infection with other respiratory pathogens in COVID-19 patients. Clin. Microbiol. Infect. 2020. [CrossRef]

Publisher's Note: MDPI stays neutral with regard to jurisdictional claims in published maps and institutional affiliations.

(C) 2020 by the authors. Licensee MDPI, Basel, Switzerland. This article is an open access article distributed under the terms and conditions of the Creative Commons Attribution (CC BY) license (http://creativecommons.org/licenses/by/4.0/). 